\title{
HUMAN IMMUNOGLOBULINS IN THERAPY. RATIONALE AND CLINICAL APPLICATIONS
}

\author{
Franco Dammacco Nicla Campobasso \\ FEDERICO PEROSA
}

Istituto di Patologia Speciale Medica e Metodologia Clinica Università degli Studi di Bari

The use of immunoglobulins (Ig) for therapeutic purposes can be attributed historically to the pioneering studies of Emil von Behring who, exactly a century ago, showed how patients with tetanus or diphtheria could acquire a passive immunity after administration of the serum from horses immunized with tetanus or diphtheria toxin, respectively. This procedure, however, had the disadvantage of a high frequency of side-effects, arising in particular from the animal origin of the protective serum and thus from its antigenicity in the recipient. It was necessary to wait about 60 years before a number of protein fractions obtained from normal human plasma became available. In fact, it was the main achievement of CoHN et al. ${ }^{8}$ to have developed a method in the early 1940 s for the alcohol fractionation of plasma. This method is still valid in essence today ${ }^{25}$, as it allows the isolation of five plasma fractions; one of these, the so-called Cohn's fraction II, accounts almost completely for the gammaglobulin antibody portion. For about 10 years, that is until the early 1950 s, Cohn's fraction II was used both prophylactically and therapeutically in some endemic and epidemic viral and bacterial diseases, including viral hepatitis and poliomyelitis ${ }^{19,22}$.

In 1952 BRUTON $^{6}$ described the first case of that special type of deficiency in humoral immunity which is now termed 'sex-linked congenital agammaglobulinemia'. In addition to suggesting a direct relationship between the abnormal susceptibility to infections and the absence of the gammaglobulin band in the electrophoretic pattern of the patient's serum, Bruton was able to show that the administration of the gammaglobulin electrophoretic fraction

Key-words: Immunization; Immunodeficiency syndromes; Immunoglobulin preparations; Immunoglobulins; Immunotherapy; Infections; Monoclonal antibodies.

Accepted for publication on February 25, 1983.

La Ricerca Clin. Lab. 13, 183, 1983. 
from the plasma of normal subjects produced a significant reduction in the recurrent infections in this patient. This observation formed the basis of what is today called replacement immunotherapy of humoral immunodeficiency syndromes and established a rational approach to the therapeutic use of human gammaglobulins.

A fundamental contribution to the study and production of plasma de. rivatives (and particularly Ig) for clinical use was also-made by ScHwick et al. ${ }^{21,39,41,42}$. Finally, in the last 10 years, human Ig preparations have been the subject of further research which has led to:

a. the acquisition of a great deal of clinical experience with standard Ig corresponding to Cohn's fraction II; $\operatorname{IgM}$;

$b$. the production of preparations with higher concentrations of IgA and/or

c. the definition of the physicochemical, immunochemical and biological characteristics of the various preparations;

$d$. procedures for the chemical or structural modifications of Ig so that it can be given by intravenous infusion; therapy.

e. a better understanding of the immediate and delayed side-effects of Ig

Each of these aspects will be briefly discussed in the following pages. Also considered will be the 'punctum dolens' of the indications, which are obvious when it is desired to produce an immunotherapeutic replacement effect, but are much more questionable in many other clinical conditions in which the mechanisms of humoral immunity are apparently not affected. Finally, some brief mention will be made of some recent and unexpected indications of Ig therapy that have been found by chance observations (the so-called serendipity), namely the use of Ig in idiopathic thrombocytopenic purpura and autoimmune neutropenia.

\section{THE PRINCIPAL IMMUNOGLOBULIN PREPARATIONS}

\section{A. Preparations for intramuscular use}

1. Conventional or standard Ig. This term refers to Ig preparations essentially obtained by the classical alcohol fractionation method of Cohn. As the start. ing material consists of a pool of normal human sera originating from 1,000 up to 5,000 donors, conventional Ig obviously contains an extremely heterogeneous group of antibodies, representative of the antibody variety present in the plasma of the normal population living in the geographical area of the donors. The large number of donors also ensures optimum comparability, in terms of titre and antibody variety, between different batches of Ig. Almost all the commercially available preparations have a $16 \%$ concentration and thus contain $160 \mathrm{mg}$ of $\mathrm{Ig} / \mathrm{ml}$, of which about $90 \%$ is formed by $\mathrm{IgG}$.

If a conventional Ig preparation is subjected to analytical ultracentrifugation, it is always possible to detect, in addition to a main peak with a sedimentation coefficient of $7 \mathrm{~S}$ corresponding to the principal monomeric portion of IgG, a minor 11-13S peak attributable to the presence of polymeric aggregates of $\operatorname{IgG}$ in the preparation (fig. 1). In view of their anticomplemen. tary activity, these aggregates can induce a spontaneous activation (that is in 
the absence of antigen) of the complement system. The administration of conventional Ig is therefore possible only by the intramuscular route, their intravenous infusion usually inducing anaphylactoid reactions that vary in severity and can even be fatal. As it will be emphasized when mentioning the side effects of Ig therapy, not even intramuscular administration always gives protection against undesirable effects, especially in patients with agamma- or dysgammaglobulinemia. The intramuscular route, however, has some obvious disadvantages ${ }^{9,18}: a$. the slow absorption of the preparation delays by about a week the attainment of therapeutic blood levels of Ig; $b$. the total quantity of Ig that can be administered by this route is rather limited: indeed, as each $\mathrm{ml}$ of the conventional preparation contains $160 \mathrm{mg}$ of $\mathrm{Ig}$, a total volume of about $10.15 \mathrm{ml}$ has to be injected for the recipient to receive $1.5 .2 \mathrm{~g}$ of $\mathrm{Ig}$, and even if this is broken up and given in several sites, it is difficult to achieve in infants and anyway induces painful local reactions.

Finally, mention must be made of another drawback of conventional Ig, which is also shared by intravenous preparations; this results from the fact that the antibody population is limited almost exclusively to the IgG class, whilst $\operatorname{IgA}$ and $\operatorname{IgM}$ are present only in traces despite their potential importance in numerous disease conditions.

2. IgA-enriched preparations. With the specific intention of compensating for the limitation of the majority of conventional Ig preparations, resulting from their almost exclusive content of $\operatorname{IgG}$ antibodies, preparations with a high IgA content have been developed in the last few years". Such IgA enriched preparations have never gained, however, general acceptance. In one study

Fig. 1-Ultracentrifugation of a preparation of conventional $\mathrm{Ig}$ with a Beckman Spinco model $\mathrm{E}$ analytical ultracentrifuge: speed, $59,780 \mathrm{rpm}$; temperature, $20^{\circ} \mathrm{C}$. The sedi. mentation proceeds from left to right. Next to the main peak with a $7 \mathrm{~S}$ sedimentation coefficient, there is a much smaller peak showing a more rapid sedimentation, prob. ably corresponding to small quantities of polymers.

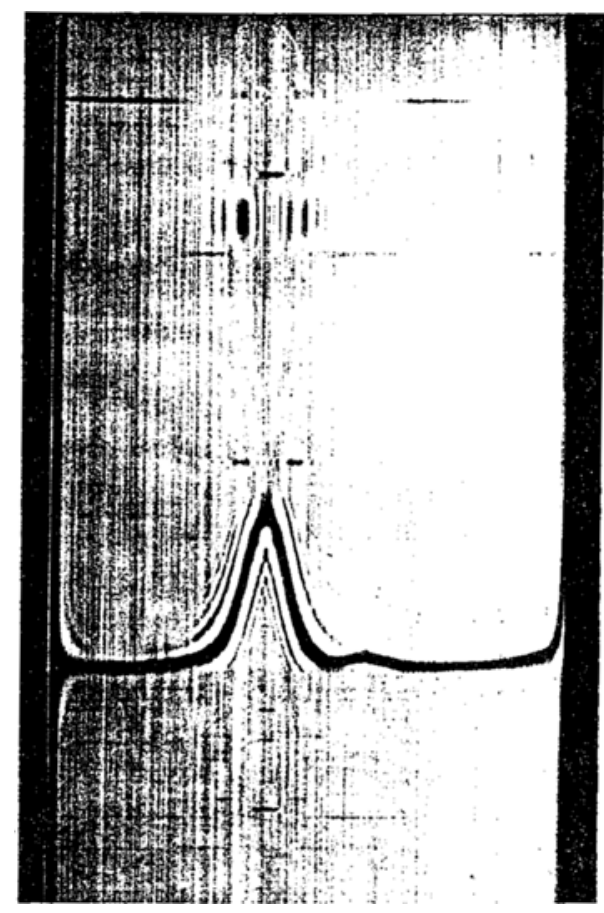


that we carried out on two different batches of one of these IgA-enriched preparations', the following mean values for the five Ig classes were found: IgG 3,909 mg/100 ml; IgA 2,504 mg/100 ml; IgM $454 \mathrm{mg} / 100 \mathrm{ml} ; \mathrm{IgD} 228$ $\mathrm{IU} / \mathrm{ml}$; IgE $964 \mathrm{IU} / \mathrm{ml}$.

Consequently, in contrast to normal plasma in which the $\operatorname{Ig} G / \operatorname{Ig} A$ ratio is about $5: 1$, these preparations had a ratio of about $1.5: 1$, which indicates a considerable enrichment in IgA. It must be emphasized that, at least in the two lots we studied, the process used for IgA enrichment also resulted in much higher $\operatorname{Ig} M, \operatorname{IgD}$ and $\operatorname{IgE}$ concentrations than those in conventional preparations. While the increase in $\operatorname{IgM}$ can be therapeutically valuable and that in $\operatorname{IgD}$ does not appear to have any therapeutic significance, the concurrent increase in IgE could have adverse effects when such a preparation is administered to atopic subjects.

The clinical significance of IgA enriched preparations comes, first of all, from their obvious use in cases of the specific deficiency of this immunoglobulin class. It should also be mentioned that certain antibodies (such as those to poliomyelitis virus) mainly belong to the IgA class, and are mostly associated with the defensive system of the superficial mucosae and external secretions, where the secretory IgA acts as a 'protective paint' ${ }^{\prime 6}$. However, experience so far ${ }^{7.18}$ seems to indicate that, in spite of its high concentration, the IgA present in the intramuscular preparations does not reach the external secretions or only does so in negligible quantities. These findings agree with the recent observations on the intestinal transport of polymeric $\lg A$ through the bile. In normal human serum, $90 \%$ of the IgA is formed of monomers, and only the remaining $10 \%$ consists of dimers and polymers. In the external secretions, however, the majority of the $\operatorname{IgA}$ is present in the form of dimers conjugated with the secretory component (SC). Polymeric IgA (but not monomeric $\operatorname{IgA}$ ) present in the circulation combines avidly with the SC that acts as a membrane receptor on the surface of hepatocytes. The IgA-SC complex penetrates the endocytic vesicles of the hepatocytes, passes through the cytoplasm of these cells and is then liberated into the bile ducts. The transport of polymeric $\operatorname{IgA}$ from blood to bile is a rapid and active process ${ }^{12,32}$.

In order to avoid undesirable reactions in the recipients, the IgA-enriched immunoglobulin preparations consist mainly of monomeric IgA. Hence, it is presumed that they are largely exempt from this active transport mechanism and may thus be found only in small quantities in the external secretions.

Finally, it must be emphasized that, as detailed metabolic studies have shown $n^{49}$ IgA (but the same remarks also apply to $\operatorname{Ig} M$ ) have a shorter half-life than IgG. Indeed, half-life ranges from 7 to 21 days for the various subclasses of $\operatorname{IgG}$, whereas mean values are 6 days for $\operatorname{IgA}$ and 5 days for $\operatorname{IgM}$. It follows that, whatever their concentration in the preparation, it is necessary to repeat the administration of IgA-enriched preparations (as well as IgM-enriched preparations) at shorter intervals than those usually used for conventional Ig in order to maintain therapeutic levels of $\operatorname{IgA}$ antibodies (and/or IgM).

3. IgM-enriched preparations - The therapeutic attempts at using IgM-enrich. ed preparations are fairly recent ${ }^{42}$ and the experience acquired with these preparations on the international scale is still limited". Their clinical usefulness, however, may have a rational basis: it is known, in fact, that the antibody 


\begin{tabular}{|c|c|c|}
\hline & & antibody concentration $/ \mathrm{ml}$ \\
\hline \multirow{7}{*}{ anti } & - measles & $250 \mathrm{IU}$ \\
\hline & - mumps & 1:1,024 complement fixing antibody \\
\hline & - whooping cough & $1: 2,560$ agglutinating antibody \\
\hline & - rubella & 8,000 hemagglutination inhibition $U$ \\
\hline & - tetanus & $250 \mathrm{IU}$ of tetanus antitoxin \\
\hline & - smallpox & $1,000 \mathrm{IU}$ \\
\hline & - hepatitis B & $100 \mathrm{IU}$ \\
\hline
\end{tabular}

Tab. 1 - Specific or hyperimmune immunoglobulins currently available.

response to Gram-negative bacteria is mainly, if not exclusively, of the IgM type and that, in addition, the IgM antibodies are about 1,000 times more active, on a molar basis, than $\operatorname{IgG}$ antibodies in terms of bacterial agglutination and complement activation ${ }^{12}$.

Like the IgA-enriched preparations, the increase in the $\operatorname{IgM}$ concentration is relative, the IgG portion nevertheless remaining quantitatively the main one. In comparison with normal human plasma in which the $\mathrm{Ig} G / \mathrm{IgM}$ ratio is about $10: 1$, this ratio increases to about 4.5:1 in IgM-enriched preparations.

These preparations also must be given by the intramuscular route, and because of the already mentioned rather short half-life of $\operatorname{IgM}$, the interval between administrations must be reduced in relation to conventional preparations in order to maintain adequate circulating levels of $\operatorname{IgM}$.

4. Specific or hyperimmune Ig . These preparations are very similar to conventional Ig preparations both in their method of preparation (alcohol fractionation) and in their antibody content which consists almost exclusively of IgG. Although resembling conventional preparations quantitatively, specific Ig differs from them in the selection of donors who are chosen among those recovering from a certain disease, or from subjects actively immunized against the etiological agent of the disease in question. This selection of donors results in an enriched IgG preparation with specific antibody activity against a certain antigen 9.28 .

There are currently available a large number of hyperimmune Ig prep. arations with a high antibody titre against whooping-cough, tetanus, etc. (tab. 1). Because of their specificity which determines their relatively high cost, hyperimmune Ig is indicated in cases in which it is desired to prevent or at any rate attenuate the clinical effects of certain infectious diseases.

\section{B. Preparations for subcutaneous administration}

Recently there has been a progressive dissemination of portable infusion apparatus that can ensure the slow subcutaneous infusion of drugs and hormones; for example, insulin in patients with juvenile diabetes and desferrioxamine in thalassemia patients, and it has been suggested that such apparatus can also be used for the therapeutic administration of Ig.

The preparations that can be used for this purpose are conventional Ig but, if necessary, slow subcutaneous infusions can obviously be used also for $\operatorname{Ig} \mathrm{A}$. 
or IgM-enriched preparations and for hyperimmune Ig. The basic apparatus consists of a small portable infusion pump (usually $15 \times 5 \times 5 \mathrm{~cm}$ ) weighing about $300 \mathrm{~g}$. The pump, powered by replaceable batteries and carried on a belt, acts on an ordinary syringe or a plastic reservoir attached to the infusion apparatus. The disposable butterfly needle is inserted into the subcutaneous tissue of the abdominal wall and the rate of administration is usually $1.2 \mathrm{ml} / \mathrm{h}$; as the volume of each infusion generally ranges from 10 to $30 \mathrm{ml}$, the duration of the infusion lasts $5.15 \mathrm{~h}$ and is therefore compatible with working hours and also with school hours for children, as well as with hours of sleep.

The results obtained so far in both adults ${ }^{4}$ and children ${ }^{47}$ seem excellent in terms of tolerance and the possibility of repeated administrations at short intervals without interfering with the normal activities of the patient, whilst at the same time ensuring the maintenance of adequate circulating levels of Ig.

\section{Preparations for oral administration}

A brief mention should be made of the recent proposal ${ }^{2}$ for the admin. istration, in the special circumstances of pediatric conditions, of conventional Ig by the oral route. In a randomized clinical study carried out in a nursery with a high prevalence of rotavirus infections, their oral administration ( $4 \mathrm{ml}$ four times a day) in the first seven days of life to immature babies (of about $2,000 \cdot 2,500 \mathrm{~g}$ ) for whom no colostrum was available, produced a signifi. cant reduction (compared with a control group treated with a placebo) in the prevalence and severity of rotavirus-induced diarrhoeic symptoms and also inhibited the excretion of the rotavirus².

Obviously, the passage of Ig through the gastrointestinal tract cannot have any appreciable therapeutic effect in the adult, as it is rapidly split and broken down to inert fragments by digestive enzymes and the intestinal bacterial flora. In immature babies, however, it has been shown ${ }^{5}$ that conventional Ig preparations retain some activity in the gastrointestinal tract, at least judging from the fact that appreciable quantities of both whole and partially digested IgG are found in their feces, probably as a result of the functional immaturity of the digestive system.

Although this is a quite interesting approach and undoubtedly deserves further investigation, it is nevertheless clear that the oral administration of conventional Ig is limited clinically to diseases occurring in the first few days of life.

\section{Preparations for intravenous administration}

These represent a definite advance over therapy with conventional Ig preparations, and though their use is still limited by their higher cost, they are the only ones that can produce a rapid and considerable therapeutic effect in severe bacterial or viral infections. In fact, the intravenous route makes it possible to infuse large quantities of $\mathrm{Ig}$ in a short time and thus to reach very rapidly an adequate antibody concentration ${ }^{9,28,41}$.

As already stated, conventional Ig preparations cannot be used intrave. nously because of their tendency to form aggregates that can activate the complement system in the absence of antigen and thus induce severe side reactions of the anaphylactic type. To adapt these preparations for intrave. nous administration, a whole series of techniques and chemical modifications 
(aimed at avoiding the formation of aggregates) have been applied on different occasions. These methods, summarized in tab. 2, can be classified broadly under the following main methods:

1. Enzyme digestion (fig. 2) - The enzymes generally used are:

a. pepsin, which splits the IgG molecule immediately after the main disulphide bonds which link their $\mathrm{H}$ chains: this gives a bivalent fragment $\left.\mathrm{F}(\mathrm{ab})_{2}\right)_{2}$, while the $\mathrm{Fc}$ fragment is broken down to peptides of small dimensions. Use of the $F\left(\mathrm{ab}^{\prime}\right)_{2}$ fragment is based on clinical experience of several years that has confirmed the very good tolerance of the product, which has consequently become one of the best known and widely used preparations administered intravenously ${ }^{39}$. The $\mathrm{F}\left(\mathrm{ab}^{\prime}\right)_{2}$ fragment, being normally provided with antigen receptor sites, obviously retains the capacity to combine with viral, bacterial and other types of antigens, and to neutralize them. However, the absence of the Fc fragment deprives the molecule of the characteristic effector functions of the Fc fragment such as the activation of complement by the classical pathway, the opsonizing action on phagocytosis, control of the molecule catabolic properties, and so on. In addition, as a result of their smaller size compared with that of intact $\operatorname{IgG}$, the $\left.F\left(a^{\prime}\right)_{2}\right)_{2}$ fragments are cleared more rapidly from the blood circulation ${ }^{28}$;

b. plasmin, whose mode of action is similar to that of papain: it produces its enzyme action in front of the $\mathrm{H}$ interchain disulphide bridges, forming two monovalent $\mathrm{Fab}$ fragments and one $\mathrm{Fc}$ fragment ${ }^{35}$. Although the product is well tolerated after intravenous administration and it has been demonstrated in vitro that the monovalent Fab fragments combine with the antigen, it is much more controversial as to whether these can actually neutralize the antigen. It is probable, indeed, that the therapeutic effects of plasmin-treated Ig preparations must be attributed to the fact that about one third of the Ig molecules are resistant to this treatment and are thus infused as whole molecules.

1. enzyme digestion:

A. $\operatorname{pepsin}(1: 100)$

B. plasmin

2. chemical modifrations:

A. treatment with $\beta$.propiolactone

B. treatment with reducing substances:

a. sulphonation

b. reduction and alkylation

c. limited sulphitolysis

3. modifications that preserve the structural integrity of the antibody molecule:

A. treatment with polyethylene-glycol (PEG)

B. treatment with hydroxyethylamide and PEG

C. absorption on DEAE-Sephadex and protection with albumin

D. treatment at $\mathrm{pH} 4$ in the presence of traces of pepsin $(1: 10,000)$

Tab. 2 . Commonest modifications of standard $1 \mathrm{~g}$ to enable intravenous administration. 


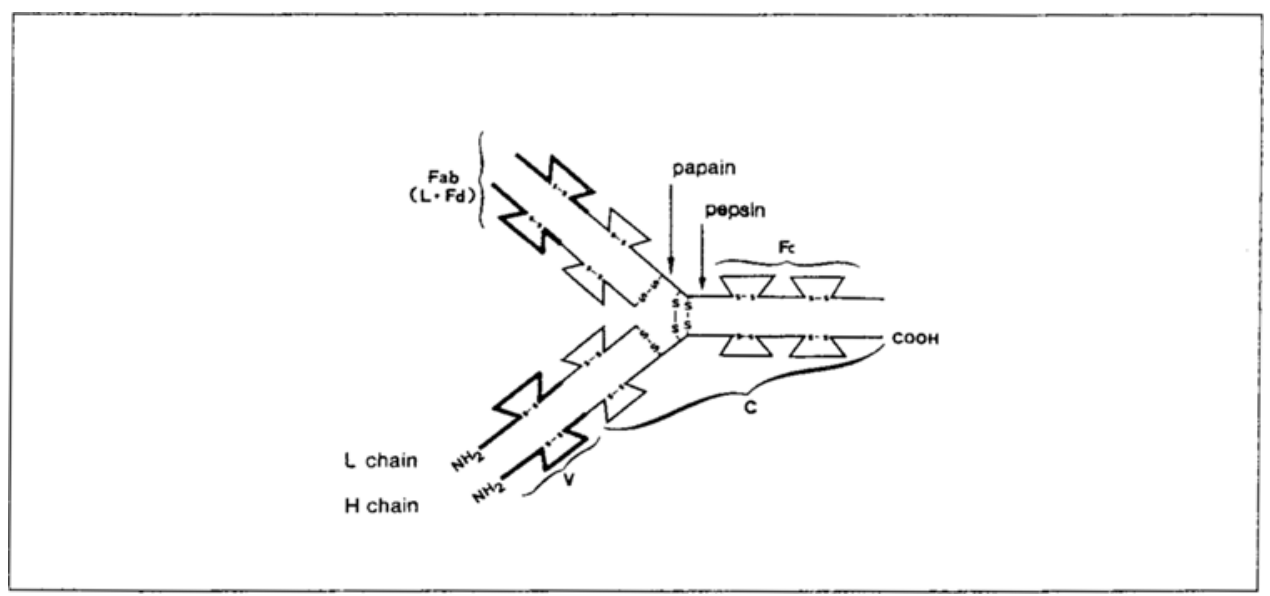

Fig. 2 - Schematic drawing of IgG molecular structure and the sites of action of the enzymes papain and pepsin. The symbols $\mathrm{V}$ and $\mathrm{C}$ correspond to the variable and the constant parts, respectively.

2. Chemical modifications. Immunoglobulins can be modified by various chemical processes all aimed at limiting or abolishing the aggregating properties. The best known of these procedures are ${ }^{35}$ :

$a$. treatment with $\beta$-propiolactone, whose alkylating action modifies the Fc segment of the Ig molecule so that the aggregates formed have litcle spontaneous complement-fixing activity. The changes in the treated $F c$ also affect the biological activities associated with these, including in particular its half-life, which is shortened;

$b$. treatment with reducing substances, which break the disulphide bridges that join the $\mathrm{H}$ chains together and link the $\mathrm{H}$ chains with the $\mathrm{L}$ chains, resulting in the loss of the molecule's anticomplementary activity ${ }^{37,38}$. In addition to the Ig sulphonate preparations developed in the United States ${ }^{30}$, this-subgroup includes an interesting product that has been recently used clinically in Germany and which has shown high efficacy and good tolerance in a trial we carried out on a group of patients with primary and secondary immunological defects ${ }^{10}$. In this preparation the Ig antibodies are subjected to a limited sulphitolysis procedure which breaks down some of the interchain disulphide bridges and thus enables the preparation to be given intravenously. An oxidation process in the circulation as well as in the tissues restores the original four chain structure of the molecule ${ }^{27}$. The preparation is supplied by the manufacturer in a lyophilized form and contains glycocol as the stabilizing agent. Its half.life in the circulation of healthy control recipients ranges from 11 to 17 days.

3. Structurally intact $I g$. In these preparations the modifications made to enable intravenous administration tend to maintain the structural integrity of the antibody molecule ${ }^{35}$. The more common methods involve:

a. treatment with polyethylene-glycol (PEG): the addition of PEG, alone or in combination with hydroxyethylamide, to ordinary preparations of conventional Ig breaks the aggregates into monomers and prevents any further 
formation of these aggregates. There remains, however, although attenuated, the capacity for the spontaneous activation of complement after PEG treatment, and this can lead to more or less severe side-effects in the recipient. In addition, these preparations usually contain high levels of prekallikrein activator ${ }^{35}$ that can cause undesirable vasoactive reactions after rapid infusion;

$b$. treatment at $\mathrm{pH}$ 4: Cohn's alcohol treatment can be used in an acid environment at $\mathrm{pH} 4$ in the presence of a low pepsin concentration $(1: 10,000)$ which at such a low concentration has a stabilizing effect on IgG without any apparent proteolytic action on the molecule itself. The combination of a low $\mathrm{pH}$ and a weak enzyme concentration is said to inhibit the formation of aggregates and makes it impossible for the preparation to have any spontaneous anticomplementary activity ${ }^{36}$, so that as a result it is well tolerated.

\section{PHYSICOCHEMICAL AND IMMUNOCHEMICAL PROPERTIES OF Ig PREPARATIONS}

Conventional Ig preparations, and those used for intravenous adminis. tration not broken down enzymatically, mainly contain monomeric IgG. Analytical ultracentrifugation of these preparations, however, shows (fig. 1) that, besides. the main $7 \mathrm{~S}$ peak of the monomers, dimers and polymers of the immunoglobulins are also generally present (although usually in small quantities). Chromatographic separation by gel filtration on a Sephadex column confirms the partial heterogeneity of the preparations that largely consist of monomers, but which also contain more or less negligible amounts of dimers and polymers as well as immunoglobulin fragments (fig. 3). These fragments, because of their low molecular weight, are eluted immediately after the main peak of the monomers and produce on the chromatogram an irregularity in the descending line of this peak or the occurrence of a small peak after that corresponding to the monomers.

The relative heterogeneity of the molecule population, in the sense that it consists of appreciable quantities of polymers in addition to the prevailing amount of monomers, obviously applies to the IgA- and IgM-enriched preparations as well.

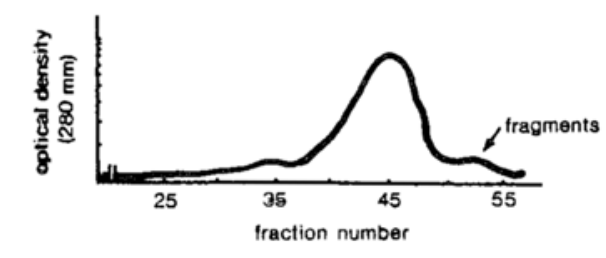

Fig. 3 - Chromatographic separation on a Sephadex column of a conventional Ig preparation. The chromatographic pattern clearly shows that the main peak of the monomers is preceded by a smaller polymer peak and is followed by another small peak in which immunoglobulin fragments are probably eluted. 
A normal quantitative distribution of the various Ig subclasses in a preparation indicates that exogenous Ig is similar to that present in normal plasma. The numerous investigations carried out ${ }^{3,43,44}$ have in fact shown that in the majority of the conventional Ig preparations the concentration of the four IgG subclasses is largely comparable to that in normal human serum. In IgA-enriched preparations this class is almost exclusively represented by the IgA1 subclass, probably because of the low circulating levels of IgA2 under normal conditions and because of the relative molecular instability of this latter subclass. Finally, as regards the distribution of the subclasses in the preparations for intravenous administration, this depends on the method used to prepare them. In the preparations not treated with enzymes the IgG subclasses are represented by normal percentages, whereas in those treated by sulphonation or with $\beta$.propiolactone the IgG3 subclass is almost completely absent. Enzyme digestion with plasmin produces an enrichment in IgG2 and the disappearance of IgG3 in the remaining IgG. Finally, pepsin digestion, by breaking down the FC fragment into peptides of small dimensions, prevents the identification and measurement of the various subclasses ${ }^{+4}$. Similar de. ductions regarding the distribution of the subclasses and the immunological integrity of the Fc fragment can also be made by immunoadsorption processes on a Sepharose column conjugated with Staphylococcus aureus protein A ${ }^{44}$.

\section{BIOLOGICAL CHARACTERISTICS OF Ig PREPARATIONS}

An important biological aspect of Ig preparations is represented by their metabolic characteristics. As a rule, the conventional preparations have metabolic reactions that are similar to those of normal Ig. Reabsorption from injection in the gluteal muscles is rather slow and the 'plateau' of their appearance in the intravascular compartment, equal to about $20-40 \%$ of the injected dose, is usually reached between the third and seventh day. The biological half-life of Ig injected intramuscularly into normal recipients is about 20.23 days $^{29}$. Naturally the above-mentioned characteristics depend on the general condition of the patient, his age and muscular activity, the total dose of Ig injected, the circulating Ig levels, and so on.

The intravenous preparations have been studied only to a limited extent as regards their metabolic properties. With the exception of Ig modified at $\mathrm{pH} 4$, whose metabolism is comparable to that of conventional Ig, the preparations modified by sulphonation or $\beta$-propiolactone have shown significant changes from standard Ig, as their half.life in the intravascular compartment is $30.40 \%$ shorter and their catabolic index is higher. Finally, in the pepsin-treated preparations which are largely formed of $\mathrm{F}\left(\mathrm{ab} \mathrm{b}^{\prime}\right)_{2}$ fragments, survival in the intravascular compartment is reduced by $60 \%$, the catabolic index is more than doubled, and the intravascular fraction reduced by $45 \%$ when compared with the corresponding characteristics of conventional $\operatorname{Ig}^{29}$. There still remains to be determined the metabolic behavior of the more recently introduced intravenous Ig preparations, including those modified by limited sulphitolysis.

The therapeutic effect of $\mathrm{Ig}$ preparations is mainly related to their content of specific antibodies against viruses, bacteria and toxins. Taking into consideration the variations in sensitivity of the different methods (agglutina. 
tion, neutralization, complement fixation, immunofluorescence, RIA, etc.) used to determine the antibody titre, many of the commercially available preparations contain, in general, the same antibodies as those present in the serum of the donors from whom these preparations were obtained. Wide variations among the various preparations have, however, been demonstrated as regards the titre of anti-HBs antibodies ${ }^{35}$.

In assessing the potential therapeutic value of Ig, it should also be mentioned that there is not always a direct correlation between the quantitative levels of $\mathrm{Ig}$ in the preparation and the protective clinical effect: that is, what is important is not the total quantity of Ig administered but rather the amount of specific antibodies to the antigen in question. It must also be borne in mind that the structural and functional integrity of the Fc segment in the administered Ig ensures the retention of those useful effector functions ascribed to the Fc segment, such as the capacity to fix the Clq fraction of complement, cytotropic activity, transport through membranes, control of the catabolic processes of the immunoglobulin molecule, etc. ${ }^{52}$. Therefore, in the preparations in which the FC fragment is broken down or altered, the antibodies retain their capacity to fix and neutralize the antigen, but lack the biological effector characteristics of the Fc segment mentioned above.

\section{INDICATIONS AND DOSES OF Ig PREPARATIONS}

The indications for Ig therapy obviously vary with the various commercially available preparations and the desired effects (tab. 3). There is no doubt as to the value and rationale of conventional Ig therapy for prophylactic purposes in cases with a primary deficiency in humoral immunity and thus in antibody formation ${ }^{28}$. This group includes Bruton type sex-linked agammaglobulinemia, common variable hypogammaglobulinemia and the different forms of dys. gammaglobulinemia with deficiencies in one or more Ig classes: in these forms the antibody deficiency is absolute or predominant, and thus the corrective effect produced by replacement therapy with exogenous Ig can often overcome recurrent infections of these disease conditions. There is an equally rational basis for Ig therapy in primary immunodeficiencies in which, in addition to the deficiency in humoral immunity, there is also a deficiency in cellular immunity (which is often quantitatively predominant): examples of such disease conditions are severe combined immunodeficiency, ataxia. telangiectasia, Wiskott-Aldrich syndrome, etc. Obviously, the replacement action of Ig therapy in these cases can only control the clinical manifestations of the disease associated with the defect in antibody formation, but not those arising from the defective cellular immunity 9.18.28.

There are, in addition, primary 'paraphysiological' immunodeficiencies for which this therapy can also sometimes be indicated, namely immunodeficiencies in premature babies and in newborn infants up to a month old (transient hypogammaglobulinemia of early infancy) in whom there is a delayed development, rather than a primary deficiency, of the immune system.

Whereas the primary immunodeficiencies are relatively rare, there is a much higher frequency of clinical conditions which induce a secondary immunodeficiency, including lymphoreticular neoplasms, acute leukemias, protein-losing syndromes (malabsorption and intestinal lymphangiectasia, 


\begin{tabular}{|c|c|c|}
\hline $\begin{array}{l}\text { preparation and route } \\
\text { of administration }\end{array}$ & indications & value \\
\hline \multirow{3}{*}{$\begin{array}{l}\text { conventional or } \\
\text { standard Ig } \\
\text { i.m. }\end{array}$} & $\begin{array}{l}\text { - primary deficiencies in antibody formation } \\
\text { (Bruton type agammaglobulinemia, } \\
\text { common variable immunodeficiency, etc.) }\end{array}$ & unquestioned \\
\hline & $\begin{array}{l}\text { - transient immunodeficiencies } \\
\text { (immunodeficiency in premature babies, } \\
\text { transient hypogammaglobulinemia of } \\
\text { early infancy) }\end{array}$ & $\begin{array}{l}\text { generally limited } \\
\text { to individual cases }\end{array}$ \\
\hline & $\begin{array}{l}\text { - secondary immunodeficiencies } \\
\text { (lymphorecicular neoplasms, protein-losing } \\
\text { syndromes, iatrogenic immunodepression, etc.) }\end{array}$ & varying from case to case \\
\hline $\begin{array}{l}\text { IgA- or IgM. } \\
\text { enriched } \operatorname{Ig} \\
\text { i.m. }\end{array}$ & - selective deficiency in $\operatorname{Ig} A$ and/or $\operatorname{Ig} M$ & not demonstrated \\
\hline \multirow[t]{2}{*}{$\begin{array}{l}\text { specific or } \\
\text { hyperimmune Ig } \\
\text { i.m. }\end{array}$} & $\begin{array}{l}\text { - prophylaxis or attenuation of some infectious } \\
\text { diseases, especially in people living } \\
\text { in communities (barracks, schools, etc.) }\end{array}$ & $\begin{array}{l}\text { depends on the specific } \\
\text { antibody titre, total } \\
\text { dose and the earliness } \\
\text { of administration }\end{array}$ \\
\hline & $\begin{array}{l}\text { - prevention of the vertical transmission } \\
\text { of HBsAg from mother to baby }\end{array}$ & demonstrated \\
\hline $\begin{array}{l}\text { conventional Ig } \\
\text { s.c. }\end{array}$ & $\begin{array}{l}\text { - identical to those of standard Ig } \\
\text { given im:; method of choice } \\
\text { for cases in which replacement therapy } \\
\text { is indicated over a protracted } \\
\text { period of time }\end{array}$ & $\begin{array}{l}\text { slower and more gradual } \\
\text { absorption; absence of } \\
\text { local reactions and the } \\
\text { possibility of infusing } \\
\text { larger quantities } \\
\text { at a single site }\end{array}$ \\
\hline $\begin{array}{l}\text { conventional Ig } \\
\text { orally }\end{array}$ & $\begin{array}{l}\text { - prophylaxis or atcenuation of rotavirus } \\
\text { diarrhoea syndromes in immature babies }\end{array}$ & $\begin{array}{l}\text { limited to the first } \\
\text { few days of life }\end{array}$ \\
\hline \multirow{4}{*}{$\begin{array}{l}\text { modified Ig } \\
\text { i.v. }\end{array}$} & $\begin{array}{l}\text { - similar to those of standard ig } \\
\text { given im. but preferred for } \\
\text { immunodepressed patients with particularly } \\
\text { severe and acute infections }\end{array}$ & $\begin{array}{l}\text { unquestioned, because of } \\
\text { the possibility of } \\
\text { reaching high blood } \\
\text { levels in a short time }\end{array}$ \\
\hline & $\begin{array}{l}\text { - severe bacterial or viral infections, } \\
\text { surgical septicemia, etc., in immunologically } \\
\text { normal patients }\end{array}$ & $\begin{array}{l}\text { debatable, because } \\
\text { of difficult } \\
\text { clinical trials }\end{array}$ \\
\hline & $\begin{array}{l}\text { - idiopathic thrombocytopenic purpura } \\
\text { in children and adults }\end{array}$ & $\begin{array}{l}\text { demonstrated in a still } \\
\text { limited number of cases }\end{array}$ \\
\hline & - autoimmune neutropenia & $\begin{array}{l}\text { so far demonstrated in } \\
\text { individual cases }\end{array}$ \\
\hline
\end{tabular}

Tab. 3 - Indications for the therapeutic use of immunoglobulins.

nephrotic syndrome), iatrogenic immunodepression (chemotherapy, irradiation, immunosuppressive drugs), and so on. Obviously, the complicating infections that frequently occur in these disease conditions can be helped by the exogenous administration of Ig.

The preparations supplemented with $\operatorname{IgA}$ or $\operatorname{IgM}$ may be indicated in selective deficiencies of these Ig classes or when it is thought that a certain antibody belongs to one of these classes and that it would be useful to supply a patient with a large quantity of antibodies belonging to this class. The use of $\operatorname{lgA}$ - and IgM-enriched preparations, however, is not free from criticism. First of all, their significantly higher cost, compared with that of conventional 
Ig, should necessarily lead to a careful selection of the patients to be treated with such preparations. In addition, it has not been clearly shown that the IgA, present in the enriched preparations of this type and given intramuscularly, may reach the external secretions to any appreciable amounts. Also, the superior therapeutic efficacy of $\operatorname{IgA}$ - or IgM-enriched preparations over that of conventional preparations ${ }^{9}$ has not been so far unequivocally demonstrated by controlled clinical trials. Finally, production of anti-IgA antibodies by the IgA-lacking recipient may be responsible for anaphylactic reactions upon repeated administrations of the IgA-enriched preparations.

Specific or hyperimmune Ig preparations are basically indicated for the prevention or at least the attenuation of certain infectious diseases, such as viral hepatitis, mumps, measles, chicken pox, etc., and especially in subjects living in communities. The use of hyperimmune Ig, therefore, ignores the often normal immunological state of the recipient: what these patients need, in fact, is a rapid external source of specific antibodies to a determined etiological agent to which they have been exposed or with which they are thought to have been in contact. The specific immunoglobulin preparations thus have an immediate defensive function before the patient can produce his own antibodies and, on the other hand, they also provide the only defence mechanism for immunologically deficient recipients who are incapable of mounting a normal antibody response.

A special mention deserves the recent finding that antihepatitis $B$ hyperimmune $\mathrm{Ig}(\mathrm{HBIg})$ has a preventive effect on the vertical transmission from mother to baby of the chronic carrier state of HBsAg. This prevention seems to be absolute when the newborn infant is injected with HBIg at 0.5 $\mathrm{ml} / \mathrm{kg}$ within $48 \mathrm{~h}$ of birth and subsequently at $0.16 \mathrm{ml} / \mathrm{kg}$ a month, for six months ${ }^{34}$. As the hyperimmune Ig can combine with the corresponding antigen and neutralize it, the injection of specific Ig on the one hand, and the corresponding vaccine on the other must be considered inappropriate, as this can lead to an inadequate response to vaccine stimulation. Exceptions to this rule, for the obvious reasons of the severity of the disease and the urgency of treatment, are tetanus and hepatitis $B$, in which the administration of the corresponding hyperimmune Ig may be allowed immediately before or imme. diately after active immunization ${ }^{28}$.

Table 4 summarizes the doses of the conventional Ig preparations. The wide differences in the recommended doses depend on the prophylactic or therapeutic purposes that are desired, the primary or secondary nature of the immunological defect, the severity of the disease process in question, and so on. In any case, both for conventional Ig and for hyperimmune or enriched preparations, there is a considerable quantitative limitation to intramuscular administration, which usually does not exceed a total volume of $10.15 \mathrm{ml}$ in the adult. The subcutaneous route using an infusion pump, although making it easier to administer larger volumes of $\mathrm{Ig}$, also has quantitative limits. It is indicated particularly when long-term replacement therapy is anticipated as in primary immunodeficiencies.

On the contrary, the intravenous preparations allow the desired amounts of Ig to be infused in a short time. Their indications are therefore substantially the same as those for conventional $\operatorname{Ig}^{1.26,31}$. On the other hand, their definitely 
HUMAN IMMUNOGLOBLLINS IN THERAPY

\begin{tabular}{|c|c|c|c|}
\hline disease & preparation & dosage & purpose \\
\hline $\begin{array}{l}\text { hypo- and } \\
\text { agammaglobulinemia }\end{array}$ & Clg* & $\begin{array}{l}1.2 \mathrm{ml} / \mathrm{kg} \text { initially; } \\
0.6 \cdot 1 \mathrm{ml} / \mathrm{kg} \text { as a } \\
\text { maintenance dose } \\
\text { every } 20-30 \text { days }\end{array}$ & prophylaxis and therapy \\
\hline viral encephalitis & $\mathrm{CIg}$ & $\begin{array}{l}0.5 \mathrm{ml} / \mathrm{kg} \text { every } \\
7.10 \text { days }\end{array}$ & therapy \\
\hline hepatitis A & $\mathrm{Clg}$ & $\begin{array}{l}0.02 .0 .05 \mathrm{ml} / \mathrm{kg} \text { in a } \\
\text { single or repeated dose }\end{array}$ & $\begin{array}{l}\text { prophylaxis recommended for subjects } \\
\text { exposed to contact infection }\end{array}$ \\
\hline $\begin{array}{l}\text { hepaticis } \\
\text { non-A non } B\end{array}$ & $\mathrm{CIg}$ & $\begin{array}{l}0.05 \mathrm{ml} / \mathrm{kg} \text { in a single } \\
\text { or repeated dose }\end{array}$ & facultative prophylaxis \\
\hline hepatitis B & SIg:" & $\begin{array}{l}0.05 \cdot 0.07 \mathrm{ml} / \mathrm{kg} \\
\text { repeated after a month }\end{array}$ & recommended for prevention \\
\hline $\begin{array}{l}\text { complications after } \\
\text { vaccination against } \\
\text { smallpox }\end{array}$ & CIg & $0.2 .0 .5 \mathrm{ml} / \mathrm{kg}$ & $\begin{array}{l}\text { prophylaxis in late first } \\
\text { vaccination (over 3.year-old) }\end{array}$ \\
\hline rubella & SIg or CIg & $\begin{array}{l}20 \mathrm{ml} \text { total dose, } \\
\text { repeated every } 4 \\
\text { weeks in the first } \\
\text { trimester of pregnancy }\end{array}$ & $\begin{array}{l}\text { facultative prophylaxis in women } \\
\text { exposed to infection }\end{array}$ \\
\hline varicella-zoster & SIg & $15.25 \mathrm{U} / \mathrm{kg}$ & $\begin{array}{l}\text { prophylaxis recommended in } \\
\text { immunodepressed subjects or in babies } \\
\text { exposed to contact infection }\end{array}$ \\
\hline measles & SIg or $\mathrm{CIg}$ & $0.25-0.5 \mathrm{ml} / \mathrm{kg}$ & $\begin{array}{l}\text { prophylaxis recommended in infants } \\
\text { up to 1.year-old or in } \\
\text { immunosuppressed subjects exposed to } \\
\text { contact infection less than } 6 \text { days before }\end{array}$ \\
\hline rabies & SIg & $.20 \mathrm{IU} / \mathrm{kg}$ & $\begin{array}{l}\text { prophylaxis recommended for } \\
\text { subjects exposed to rabid animals }\end{array}$ \\
\hline tetanus & SIg & $\begin{array}{l}250 \text { U prophylactically } \\
3,000 \cdot 6,000 \mathrm{U} \\
\text { therapeutically }\end{array}$ & $\begin{array}{l}\text { prophylaxis and therapy following } \\
\text { exposure of subjects not } \\
\text { immunized or incompletely } \\
\text { immunized, or immediately } \\
\text { at the time of diagnosis }\end{array}$ \\
\hline Rh-isoimmunization & SIg & $\begin{array}{l}1 \text { vial }(200.300 \mu \mathrm{g}) \\
\text { for every } 15 \mathrm{ml} \text { of } \\
\text { exposure to } \mathrm{Rh}^{+} \text {blood }\end{array}$ & $\begin{array}{l}\text { prophylaxis recommended in } \\
\mathrm{Rh}(\mathrm{D}) \text {-negative mothers at the time } \\
\text { of birth of a } \mathrm{Rh} \mathrm{h}^{+} \text {infant, } \\
\text { or after transfusion of } \mathrm{Rh}^{+} \text {blood } \\
\text { to Rh-negative mothers }\end{array}$ \\
\hline
\end{tabular}

" CIg: conventional or standard immunoglobulins.

* SIg: specific immunoglobulins.

Tab. 4 - Advisable doses for human immunoglobulins given by the intramuscular route.

higher cost and their potentially higher frequency of side-effects dictate a rigorous selection of patients for intravenous treatment: the severity and acuteness of the infectious disease are important determining factors in the choice of preparation and the route of administration, as well as of the dosage, which in particularly serious cases can reach $1.2 \mathrm{~g} / \mathrm{kg}$ body weight by the intravenous route. It should be remembered that, because of the rather short biological half-life of Ig given intravenously, it is necessary to repeat the infusions fairly frequently in order to maintain therapeutically effective blood levels of Ig. 
Ig therapy is being increasingly used for other indications, but this is much more debatable. We refer here in the first place to recurrent infections of the upper respiratory tract that occur with an abnormal frequency in some children, and secondly to severe bacterial infections and surgical septice. mias in patients with no definite immunological defect. Although clinical observations would seem to attribute empirically some therapeutic efficacy to Ig treatment (conventional Ig in the first case and intravenous Ig in the second), definite conclusions will only be reached by controlled and randomized clinical studies. The argument usually adopted in favour of the value of this type of therapy is that circulating Ig levels that are within the normal range do not necessarily indicate a normal immunological capacity to react against the etiological agent responsible for the infectious process; indeed, in severe infections with an acute or subacute course there can be a rapid consumption of the patient's own antibodies which cannot be replaced in a short time by the formation of new specific antibodies ${ }^{35}$. In such situations with a transient immunodeficiency an exogenous supply of $\mathrm{Ig}$ would thus have a useful compensatory function.

Finally, two additional indications of $\mathrm{Ig}$ therapy have been recently suggested as a result of chance observations, possibly leading to interesting practical developments. The intravenous treatment with polyvalent Ig preparations at high doses $(1.1 .5 \mathrm{~g} / \mathrm{kg}$ body weight) can produce a transient regression of the thrombocytopenia in a high percentage of patients, both children $^{20}$ and adults ${ }^{16}$, with idiopathic thrombocytopenic purpura. As the platelets in these cases are mostly functioning normally, a restoration of their normal numbers, although of short duration, could allow these patients to undergo surgery without any particular risks. A similar beneficial effect, in terms of a transient increase in total leukocyte counts and neutrophil numbers, has been observed in autoimmune neutropenia ${ }^{33}$, in which intravenous treatment with high doses of $\mathrm{Ig}$ is thus a valid alternative to corticosteroids and cytostatics. In both these disease conditions the therapeutic effect is possibly due to a transient block of the reticuloendothelial system at the level of the Fc fragment receptors, with a consequent impairment of the function of the spleen in capturing and removing platelets or neutrophils from the circulation ${ }^{16}$.

\section{SIDE-EFFECTS OF Ig THERAPY}

The therapeutic use of conventional intramuscular Ig preparations is usually free from undesirable side-effects; if they do occur, they are generally the result of the complement activation. Although the activation of comple. ment by antigen-antibody complexes has a beneficial effect on the host as it promotes the removal of the foreign antigen, this phenomenon is quite different from the spontaneous complement activation that occurs in the absence of antigen and which is due to the preparation containing Ig aggregates formed during the alcohol fractionation of the plasma.

The undesirable effects that can follow Ig therapy may be either immediate or delayed. The immediate effects appear within a few minutes up to some hours after intramuscular injection of the preparation and, with intravenously administered preparations, even in the course of the infusion itself. The 
symptoms can vary from case to case and range from simple skin eruptions, sometimes accompanied by nausea and vomiting, to syndromes of considerable severity corresponding to shock of the anaphylactic type (tab. 5). As already stated, the commonest cause of such side effects is the spontaneous activation of complement induced by the presence of macromolecular aggregates in the preparation; this complication appears to be of particular severity in patients with hypo and dysgammaglobulinemia ${ }^{\text {t5}}$. Although occurring less frequently, there are immediate side-effects that can be ascribed to other mechanisms such as, for example, the already mentioned occurrence of anti-IgA antibodies in the circulation of patients with a selective $\operatorname{IgA}$ deficiency ${ }^{11,48}$, or the increased concentration of $\operatorname{IgE}$ in some IgA- or IgM-enriched preparations when these are administered to atopic subjects.

Compared with the intramuscular route, subcutaneous infusion seems to have a lower frequency of side-effects. ${ }^{4}$. In contrast, the intravenous $\mathrm{Ig}$ preparations appropriately modified as mentioned above do produce un desirable effects in about one fifth of those receiving them, although these side-effects are generally not severe (tab. 5). Exceptions to this are the preparations modified by pepsin digestion and thus containing the $F\left(a b^{\prime}\right)_{2}$ fragment, which are tolerated very well after intravenous administration in that complement cannot be activated owing to the absence in these preparations of the FC fragment. To prevent the commonest side-effects produced by intravenous Ig, it is suggested that the patient should be given as premedication a single dose of hydrocortisone (usually $200 \mathrm{mg}$ in the adult) ${ }^{17}$, or $600 \mathrm{mg}$ of aspirin half an hour before the infusion ${ }^{31}$.

In addition to the immediate side-effects, Ig treatment may have some delayed risks, although these are more potential than real and include rather rare reports of viral hepatitis ${ }^{23}$, the possibility of isoimmunization as a result of the formation of anti-Gm antibodies, and the renal deposition of immune complexes with subsequent damage to this organ.

\section{OTHER IMMUNOLOGICAL EFFECTS INDUCED BY Ig THERAPY}

In addition to the replacement immunotherapeutic action which is clinically desired and well recognized from the biological point of view, the Ig preparations can produce other immunological effects in the recipient. It has been known for about 20 years that the passive administration of $19 \mathrm{~S}$ and $7 \mathrm{~S}$ antibodies (corresponding largely to the IgM and IgG classes) produces a specific inhibition of the antibody response in the recipient ${ }^{24}$. More recently, however, it has been observed that circulating immune complexes are present in a high percentage of normogammaglobulinemic patients with recurrent infections of the upper respiratory tract. The single or repeated administration of an Ig preparation, regardless of the route of administration, produces in these patients a definite quantitative reduction in the circulating levels of immune complexes and sometimes their complete removal from the bloodstream ${ }^{13,14,40}$. It is recognized that some immune complexes, because of their characteristics (antigen:antibody ratio, degree of polymerization, molecular size, etc.), can regulate the activation of $T$ and $B$ lymphocytes and affect the presentation of the antigen on the surface of macrophages ${ }^{51}$. It is interesting to hypothesize, therefore, that the partial or complete removal of some 


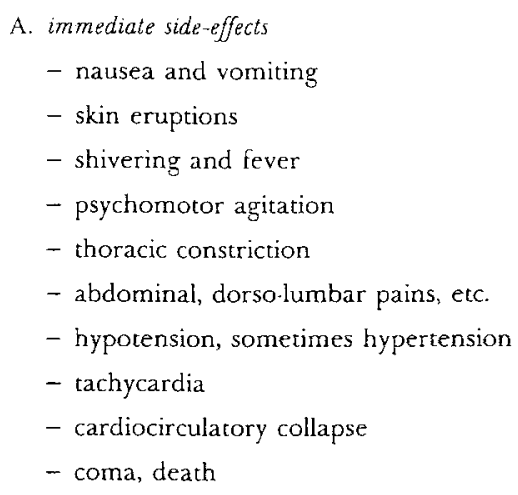

Tab. 5 - Possible side-effects of immunoglobulin therapy.

immune complexes from the circulation could be a mechanism by which Ig preparations produce their claimed therapeutic action in patients with normal circulating levels of $\mathrm{Ig}^{40}$. It is also probable that the sometimes dramatic regression of the symptoms of polyarthralgias observed in some hypogammaglobulinemic patients after treatment with Ig could be due to a similar 'clearance' mechanism acting on circulating immune complexes ${ }^{50}$.

The intramuscular administration of conventional Ig to normal subjects has recently been studied as regards the effects of this administration on some lymphocyte functions. In particular, a marked reduction has been observed in the proliferation of $T$ and $B$ lymphocytes induced by pokeweed mitogen, as well as a significant and persistent reduction in the maturation process of $B$ lymphocytes and plasma cells ${ }^{15}$. The possible presence of anti-Ia aggregates and/or antibodies in the preparation could perhaps, at least partly, explain these effects. The practical significance of the modifications of these lymphocyte functions on the therapeutic effect of $\mathrm{Ig}$ in patients with immunodefi. ciencies remains to be defined.

\section{CONCLUSIONS AND FUTURE PROSPECTS}

From the first attempts at passive immunization with heterologous serum, carried out by von Behring about 100 years ago, the administration of human Ig for prophylactic and therapeutic purposes has gradually become more widespread and it has presently gained acceptance as one of the best known methods of replacement immunotherapy for the primary and secondary immunodeficiency syndromes.

Standard Ig preparations still retain their value, their main limitation being the relatively small volume that can be injected intramuscularly. Recently, other preparations have been made available (enriched with IgA or IgM, spe. cific or hyperimmune Ig) which have a greater specificity although sharing the same limitations as the former preparations.

A decisive advance has been made by procedures that modify the Ig preparations so that they can be given intravenously, thus allowing the ad. 
ministration of large quantities of Ig in a short time. Discussion is still open on the indications and optimum dosages for Ig therapy. These appear to be clear and unquestionable in cases of definite deficiencies in humoral immunity, but are debatable in severe acute infections (especially if of undetermined etiology) and in recurrent infections of the upper respiratory tract in patients with an apparently normal immune system. The uncertainty in these cases arises from the difficulty of carrying out controlled clinical studies because of the usual delay (and sometimes because of the lack) in the identification of a definite etiology for each individual case, as well as for the general lack of information about the antibody titre of the various preparations.

As regards trends and aims for the future, efforts should be directed to the development of preparations that approach as nearly as possible to the following 'ideal' characteristics, namely: $a$. structural and functional integrity of the Ig molecules; $b$. a high content of IgM; $c$. absence of macromolecular aggregates; $d$. inability to activate complement spontaneously; $e$. normal survival in vivo; $f$. high antibody titres.

Finally, it may be envisaged that, with the increasing development of hy. bridoma techniques, human monoclonal antibodies will shortly become available and these will have a useful therapeutic effect in controlling infections of known etiology as well as in regulating the immune response of the patient.

\section{REFERENCES}

1. Ammann A.J., ashman R. F., Buckley R. H., Hardie W. R., Krantmann H. J., Nelson J., Ochs H., Stiehm E. R., Tiller T., WaRA D. W., WedGwood R.: Use of intravenous $\gamma$-globulin in antibody immunodeficiency: results of a multicenter controlled trial . Clin. Immunol. Immunopath. 22, 60, 1982.

2. Barnes G. L., Doyle L. W., Hewson P. H., Knoches A. M. L., Maclellan J. A., Kitchen W. H., BIshop R. F.: A randomised trial of oral gammaglobulin in low birth weight infants infected with rotavirus - Lancet $i, 1371,1982$.

3. Beck O. E., KaIser P. E.: Distribution of human IgG subclasses in commercial intravenous immunoglobulin preparations. A rate nephelometric method - Vox Sang. (Basel) 41, 79, 1981.

4. Berger M., Cupps T.R., FAuci A. S.: Immunoglobulin replacement therapy by slow subcutaneous infusion. Ann. intern. Med. 93, 55, 1980.

5. Blum P. M., Phelps D. L., Ank B. J., Krantmann H. J., Stiehm E. R.: Survival of oral human immune serum globulin in the gastrointestinal tract of low birth weight infants . Pediat. Res. 15, 1256, 1981.

6. BRuton O. C.: Agammaglobulinemia - Pediatrics 9, 722, 1952.

7. Cocozza R., Triggiani M., Dammacco F.: Esperienze clinico-immunologiche con un nuovo preparato di immunoglobuline umane arricchite in IgA - Folia allerg. immunol. clin. 26, $151,1979$.

8. Cohn J. E., Strong L. E., Hughes W. L., Mulford D. J., Ashworth J. N., Melin M., Taylor A. C.: Preparation and properties of serum and plasma proteins - J. Amer, chem. Soc. 68 , $459,1946$.

9. Dammacco F., Miglietta A., Pantaleo G., Bonomo L.: La terapia con immunoglobuline nella pratica clinica: indicazioni, applicazioni e limiti. In: Atti $2^{\circ}$ Simp. internaz. Microbiol. clin. Roma, 7.8 novembre 1980. Palombi Editori, Roma, 1981; p. 147.

10. Dammacco F., Perosa F., Campobasso N.: Esperienze cliniche con un nuovo preparato di immunoglobuline per via endovenosa - (In preparazione)

11. Dammacco F., Tursi A., Lucivero G., Bonomo L.: Selective IgA deficiency: a heterogeneous immunodeficiency syndrome - La Ricerca Clin. Lab. 6 (Suppl. 3), 45, 1976. 
12. Delacroix D. L., Reynaert M., Pauwels S., Geubel A. P., Vaerman J.P.: High serum levels of secretory IgA in liver disease. Possible liver origin of the circulating secretory component - Digest. Dis. Sci. 27, 333, 1982.

13. Delire M., Masson P. L.: The detection of circulating immune complexes in children with recurrent infections and their treatment with human immunoglobulins . Clin. exp. Immunol. $29,385,1977$.

14. Delire M., Petit B., Fiasse L., Masson P. L.: The therapeutic efficacy of human immunoglobulins as a function of their in vitro antibody activity toward circulating antigens in children with recurrent infections of the upper respiratory tract - J. clin. lab. Immunol. 4, $159,1980$.

15. Durandy A., Fischer A., Griscelli C.: Dysfunctions of pokeweed mitogen-stimulated T and B lymphocyte responses induced by gammaglobulin therapy - J. clin. Invest. 67, 867, 1981.

16. Fehr J., Hofmann V., Kappeler U.: Transient reversal of thrombocytopenia in idiopathic thrombocytopenic purpura by high-dose intravenous gamma-globulin - New Engl. J. Med. $306,1254,1982$.

17. Gislason D., Hanson L. A., Kjellman H., Ljunggren C., Malmberg R.: Intravenous gam ma-globulin infusions in patients with hypo-gamma-globulinemia. Prevention of adverse reactions with corticosteroids . Vox Sang. (Basel) 34, 143, 1978.

18. Hitzic W. H.: Therapeutische Anwendung von Immunoglobulinen bei Kindern . Blut 40, 215,1980 .

19. Hitzic W. H., MÜNTENer U.: Conventional immunoglobulin therapy - Birth Defects (orig. Article ser.) $11,339,1975$.

20. Imbach P., Barandun S., d'Apuzzo V., Baumcartner C., Hirt A., Morell A., Rossi E., SCHÖNI M., VEST M., WAGNER H. P.: High.dose intravenous gammaglobulin for idiopathic thrombocytopenic purpura in childhood . Lancet $i, 1228,1981$.

21. Internatronal Forum: Which is the factual basis, in theory and clinical practice, for the use of intravenous gammaglobulin in treatment of severe bacterial infections? . Vox Sang. (Basel) 37, 116. 1979.

22. JANEwAY C. A., Rosen F. S.: The gammaglobulins. IV. Therapeutic uses of gammaglobu lins - New Engl. J. Med. 275, 826, 1966.

23. John T. J., Ninan G. T., Rajagopalan M. S., John F., Flewett T. H., Francis D. P., ZUCKERMAN A.J.: Epidemic hepatitis B caused by commercial human immunoglobulin . Lancet $i, 1074,1979$.

24. KINKELSTEIN M. S., UHR J. W.: Specific inhibition of antibody function by passively admin. istered $19 S$ and $7 S$ antibody. Science 146, 67, 1964.

25. Kistler P., Nitschmann H.: Large scale production of human plasma fractions - Vox Sang. (Basel) 7, 414, 1962 .

26. Magilayy D. B., Cassidy J. T., Tubergen D. G., Petty R. E., Chrisholm R., McCall K.: Intravenous gammaglobulin in the management of patients with hypogammaglobulinemia. J. All. clin. Immunol. 61, 378, 1978.

27. Masuho Y., Tomibe K., Watanabe T., Fukumoto Y.: Development of an intravenous gammaglobulin with $\mathrm{FC}$ activities. II. Reconversion of S-sulfonated human gammaglobulin into the original gammaglobulin - Vox Sang. (Basel) 32, 290, 1977.

28. Memorandum from an IUIS/WHO Meeting: Appropriate uses of human immunoglobulin in clinical practice - Bull. Wld Hlth Org. 60, 43, 1982.

29. Morell A., Schürch B., Ryser D., Hofer F., Skvaril F., Barandun S.: In vivo behaviour of gammaglobulin preparations - Vox Sang. (Basel) 38, 272, 1980.

30. Nolte M. T., Prrofsky B., Gerritz G. A., Golding B.: Intravenous inmunoglobulin therapy for antibody deficiency . Clin. exp. Immunol. 36, 237, 1979.

31. Ochs H. D.: Prophylactic treatment of immunodeficiency syndromes with intravenous gammaglobulin - Vox Sang. (Basel) 37, 126, 1979.

32. Orlaivs E., Peppard J., Reynolds J.. Hal.l J. G.: Rapid active transport of immunoglobulin A from blood to bile - J. exp. Med. $147,588,1978$. 
33. Pollack S., Cunningham Rundles C., Smithwick E. M., Barandun S., Good R. A.: High.dose intravenous gammaglobulin for autoimmune neutropenia . New Engl. J. Med. 307, 253, 1982.

34. Reerink H. W., Reerink-Brongers E. E., Lafeber-Schut B. J. T., Kalshoven-Benschop J., BRUmmelhuis H. G. J.: Prevention of chronic HBsAg carrier state in infants of HBsAg.positive mothers by hepatitis B immunoglobulin - Lancet $i$, 436, 1979.

35. Römer J., Morgenthaler J. J., Scherz R., Skvaril F.: Characterization of various immuno globulin preparations for intravenous application. I. Protein composition and antibody content - Vox Sang. (Basel) 42, 62, 1982.

36. Römer J., SpÄTH P. J., SKVARIL F., NYDegGer U. E.: Characterization of various immunoglobulin preparations for intravenous application. II. Complement activation and binding to Staphylococcus protein A - Vox Sang. (Basel) 42, 74, 1982.

37. Schroeder D. D., Tankersley D. L., Lundblad J. L.: A new preparation of modified immune serum globulin (human) suitable for intravenous administration. I. Standardization of the reduction and alkylation reaction - Vox Sang. (Basel) 40, 373, 1981

38. Schroeder D. D., TANKersley D. L., Lundblad J. L.: A new preparation of modified immune serum globulin (human) suitable for intravenous administration. II. Functional characteriza tion - Vox Sang. (Basel) 40, 383, 1981.

39. Schultze H. E., Schwick H. G.: Über neue Möglichkeiten intravenöser GammaglobulinApplikation - Dtsch. med. Wschr. 87, 1643, 1962.

40. Schwenk H. U., Baenkler H. W.: Effect of gammaglobulin injection on circulating immune complexes in various diseases - Europ. J. Pediat. 131, 43, 1979.

41. Schwick H. G.: A survey of the production of plasma derivatives for clinical use . Vox Sang. (Basel) 23, 82, 1972.

42. Schwick H. G., Fischer J., Geiger H.: Human IgA and IgM globulins for clinical use Progr. immunobiol. Standard. 4, 86, 1970.

43. Skvaril F., Probst M., Audran R., Steinbuch M.: Distribution of IgG subclasses in commercial and some experimental gammaglobulin preparations - Vox Sang. (Basel) 32 , $335,1977$.

44. Skvaril F., Roth-Wicky B., Barandun S.: IgG subclasses in human gammaglobulin preparations for intravenous use and their reactivity with Staphylococcus protein A. Vox Sang. (Basel) 38, 147, 1980.

45. Soothill J. F.: Reactions to immunoglobulin. In: Hypogammaglobulinaemia in the United Kingdom - MRC Spec. Rep. Ser. No. 310, 1971.

46. Tomasi T. B. Jr., Bienenstock J.: Secretory immunoglobulins - Advanc. Immunol. 9, 1, 1968.

47. Ucazio A. G., Duse M., Re R., MANcill G., Burcio G. R.: Subcutaneous infusion of gammaglobulin in management of agammaglobulinaemia - Lancet $i, 226,1982$.

48. VyAs G. N., Fudenberg H. H.: Isoimmune anti-IgA causing anaphylactoid transfusion reactions - New Engl. J. Med. 280, 1973, 1969.

49. Waldmann T. A., Strober W.: Metabolism of immunoglobulins - Progr. Allergy 13, 1, 1969.

50. Webster A. D. B., Loewi G., Dourmashkin R. D., Golding D. N., Ward D. J., Asherson G. L. Polyarthritis in adults with hypogammaglobulinaemia and its rapid response to immunoglobulin treatment . Brit. med. J. i, 1314, 1976.

51. WHO: The role of immune complexes in disease. Report of a WHO scientific group. Technical Report Series 606. World Health Organization, Geneva, 1977.

52. WinKELHAKE J. L.: Immunoglobulin structure and effector functions - Immunochemistry $15,695,1978$.

Requests for reprints should be addressed to:

Franco Dammacco

Istituto di Patologia Speciale Medica e Metodologia Clinica

Università degli Studi di Bari, Policlinico Viale Ennio, T012.t Bari - Italia 